一における糖の溶出曲線の作成.

3. システインー硫酸法……i ) 糖代謝中間体の消長 の追跡. ii）メチルペントースの定量. iii）セド ヘプチュロースの定量.

4. システインーカルバゾール-硫酸法……ケトース類 の定量.

5. カルバゾール-硫酸法……アルドヘキソース類の 定性.

6. オルシノール-硫酸法……正キソース類の同定.

なお，糖が 1 種類のときは，いずれの方法も定量法と なりうることはいうまでもない.（つづく） (ふくい・さくぞら)

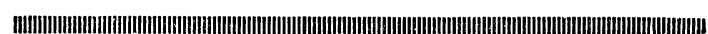

東京医歯大助教授 佐久間 昭 著

薬効のうらづけ

一薬理学ノートー

B 6 判 320 頁, 600 円

M. F. Perutz 著 水野・飯高・岡本 訳

分子生物学入門

A 5 判 180 頁, 540 円

柴田承二・名取信策・宇田川俊一 編

List of Fungal Products

全英文, B 5 判 150 頁, 1,700 円

By S. Aiba, A. E. Humphrey and N.F. Millis

\section{Biochemical Engineering}

全英文, B 5 判 350 頁， 3,600 円

東京都文竞区本悢 7-3 電話 (811) 8814 ; 振替東京 59964

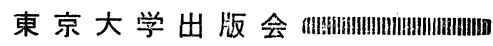

\section{化学の空}

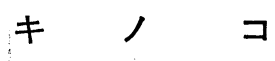

香りのよいマッタケは, 秋の味覚の王者であろろ. 春秋二季に発生するが，秋のものが本ナバとよばれ， とくに賞味されている．この香りの成分については, マッタケアルコール $\left(\mathrm{CH}_{3}\left(\mathrm{CH}_{2}\right)_{4} \mathrm{CHOHCH}=\mathrm{CH}_{2}\right.$ octene-3-ol), トランス桂皮酸メチルエステルがその 主なものであることが明らかにされている。しかし， マツタケがどらしてアカマツの根だけに菌根を形成す るのかといら根本問題はまだ解明されていないし，も ちろん人工的に栽培することもできない.

日常，私たちがよくたべるシイタケやマッシュルー ム（ツクリタケ二西洋マッタケ）は，人工栽培されて いるので, もはや季節感がなくなっている. シイタタ は木材腐朽菌の一種で，コナラ，クヌギなどを原木と して栽培されている.マッシュルームは，腐熟した馬 粪がないと生えないし, 温度, 湿度の調節がたいへん むずかしくて，人が指さしても生えてこないといわれ るほどである。

一方，キノコの中毒も非常に多く，古くからたくざ んの毒キノコが知られている. 中央ヨーロッパの森林 地带で 9 月ごろによくみられる緑黄色のタマゴテング タケは猛毒として知られて抢り, 毒成分については, 1937 年から Wieland 父子 2 代にわたって研究され, phalloidin ( I a), phalloin ( I b), phallacidin( I c), $\alpha-, \beta-, \gamma$-amanitin, amanin など, みなインドール誘

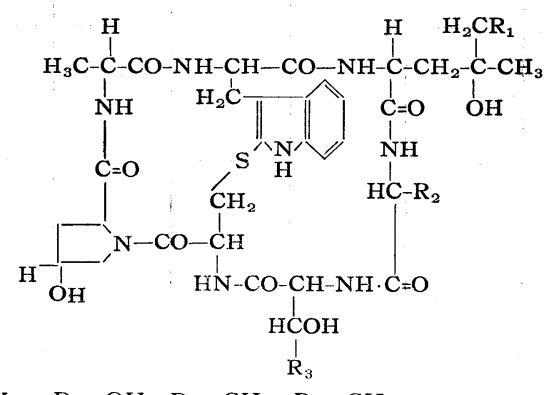

I a : $\mathrm{R}_{1}=\mathrm{OH}, \quad \mathrm{R}_{2}=\mathrm{CH}_{3}, \mathrm{R}_{3}=\mathrm{CH}_{3}$

I b : $\mathrm{R}_{1}=\mathrm{H}, \quad \mathrm{R}_{2}=\mathrm{CH}_{3}, \quad \mathrm{R}_{3}=\mathrm{CH}_{3}$

I c : $\mathrm{R}_{1}=\mathrm{OH}, \mathrm{R}_{2}=\mathrm{CH}\left(\mathrm{CH}_{3}\right)_{2}, \mathrm{R}_{3}=\mathrm{COOH}$ 
導体を含む環状ペプチドであることが明らかにされ た。これと同属の赤色のペニテングタケは，一名アカ ハェトリタケといい, ヨーロッパでは古くからハェを 捕殺することでよく知られた毒キノコで，F.Kögl が その毒成分として, muscarine(II)および muscaridine (III)を単離確認している。

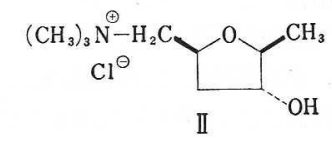
$\mathrm{H}_{3} \mathrm{C}-\mathrm{CH}-\mathrm{CH}-\mathrm{CH}_{2}-\mathrm{CH}_{2}-\mathrm{N} \oplus \mathrm{Cl}^{\oplus}\left(\mathrm{CH}_{3}\right)_{3}$
। 1
$\mathrm{OH} \mathrm{OH}$

\section{III}

わが国の毒キノュの 1 つにブナの朽木に生える夜光 性のッキヨタケがある。この毒成分が抗腫煌性もある<smiles>[R]CC1(C)C=C2C(=O)C(C)(O)C3(C=C2C1O)CC3</smiles>

$\mathrm{Na}: \mathrm{R}=\mathrm{OH}$

$\mathrm{Nb}: \mathrm{R}=\mathrm{H}$ ことがわかり, 北大の松本, 東北大の中西両教授により lampterol (IVa) と名づけられ， 構造も解明された。しかし， この物質は, ヨーロッパに広 く分布するカヤタケ属のキノ コから得られた抗菌性物質 (Na: illudin-S, Nb: illudin-M) の1つ (illudin-S) と同一物であることが 確認された. わが国のカヤタケ属のキノコの1つドク ササュ（一名, ヤケドキン）は, たべてから数日後に 神経痛様の手足の痛及を特こすことが知られて拉り， その成分に興味がもたれている。

命には別状はないが，風変わりな中毒を和こすキ， コがいろいち知られている，その1つが，メキシコの 幻覚性のシビレタケで，その毒成分は，インドール誘 導体の psilocin (V), psilocybin（V) であることが A. Hofmann により明らかにされ，合成もされた。こ<smiles>[R]P(=O)(O)O</smiles>

の成分は, シビレタケ 属のキノコに広く存在 していることがわかっ た.わが国のシビレタ ケは, 一名ワライタケ モドキとよばれ，たべ ると狂燥状態になると いわ机ているし、オオワライタケ（チャツムタケ属）， ワライタケ（ヒカゲタケ属）もその名のごとく奇妙な 中毒を怙こすといわれている。しかし生物試験がむず かしく，有効成分はまだ確認されていないが，3 年前

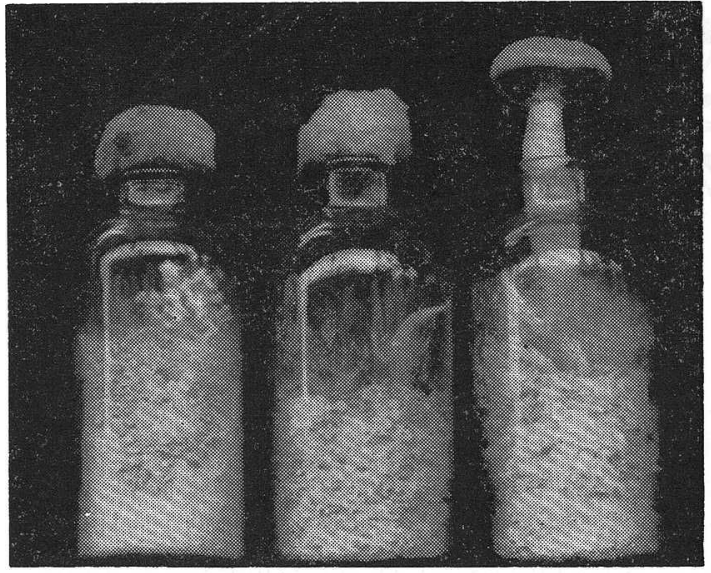

から鳥取大の初田教授の研究室でオオワライタケの人 工栽培に成功している（上の写真は，初田教授上り提 供された).

キノコには旨味をもつものが多く、たくさんのアミ 八酸や糖類が含有されている. 東北大の竹本教授は, 東北地方にある 2 つの食用キノコから味のよい新しい アミ/酸をとりだしている１つは，八土の捕殺性が あるが食用にもなるハエトリシメジで, 酸性了ミノ酸 が単離され，属名に因んで,トリコロミン酸 (VI) $(\alpha-$ ! amino-3-oxo-isoxazolidine-5-acetic acid) と名づけ<smiles>NC(C(=O)O)C1CC(O)NO1</smiles>

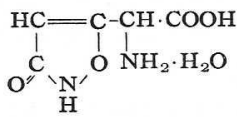
VIII

られた。これは旨味のある柱状結晶であるが，0.01\% の水溶液で八土を殺すといら．も51つは，外形が毒 キノコのテングタケとよく似ているが，食用になるイ ボテングタケ（一名，ハエトリモドシ）で，やはりハ エを捕殺するのに利用されている。このキノコから， イボテン酸 (VIII) ( $\alpha$-amino-3-oxo-4-isoxazoline-5acetic acid) と名づけられたアミノ酸が単離された。 これも旨味のある無色柱状晶で，八土を殺す性質もあ る.また、ベニテングタケ、テングタケにるこのアミ ノ酸が存在し，その殺八エ成分であることが明らかに

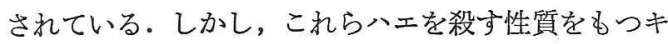
ノコに、どうしてハェが集まってくるのかまったく不 思議である。

このように, キノコには多種多様の化合物が存在し ているが，これらの含有成分とキノコの種類との関連 性をしらべていくことも興味深い問題である。 